\title{
вмј Global Health COVID-19: maintaining essential rehabilitation services across the care continuum
}

\author{
Janet Prvu Bettger (D) ,,2 Andrea Thoumi, ${ }^{2}$ Victoria Marquevich, ${ }^{3}$ \\ Wouter De Groote, ${ }^{4}$ Linamara Rizzo Battistella, ${ }^{5}$ Marta Imamura, ${ }^{5}$ \\ Vinicius Delgado Ramos, ${ }^{6}$ Ninie Wang, ${ }^{7}$ Karsten E Dreinhoefer, ${ }^{8}$ Ariane Mangar, ${ }^{9}$ \\ Dorcas B C Ghandi, ${ }^{10}$ Yee Sien Ng, ${ }^{11}$ Kheng Hock Lee, ${ }^{12}$ John Tan Wei Ming, ${ }^{13}$ \\ Yong Hao Pua, ${ }^{13}$ Marco Inzitari, ${ }^{14}$ Blandina T Mmbaga, ${ }^{15}$ Mathew J Shayo, ${ }^{16}$ \\ Darren A Brown, ${ }^{17}$ Marissa Carvalho, ${ }^{18}$ Mooyeon Oh-Park, ${ }^{19}$ Joel Stein ${ }^{20}$
}

To cite: Prvu Bettger J, Thoumi A, Marquevich V, et al. COVID-19: maintaining essential rehabilitation services across the care continuum. BMJ Global Health 2020;5:e002670. doi:10.1136/ bmjgh-2020-002670

Received 16 April 2020 Revised 23 April 2020 Accepted 24 April 2020

\section{Check for updates}

\section{Author(s) (or their} employer(s)) 2020. Re-use permitted under CC BY-NC. No commercial re-use. See rights and permissions. Published by BMJ.

For numbered affiliations see end of article.

Correspondence to Dr Janet Prvu Bettger; janet.bettger@duke.edu

\section{INTRODUCTION}

COVID-19 is overwhelming healthcare services and healthcare workers globally. The response, appropriately, is on the ability to care for people who become critically ill, protect their carers and keep people physically distanced. However, this response has shifted what is considered and how to provide essential healthcare services. Rehabilitation services, which optimise physical and cognitive functioning to reduce disability, are a core component of high-value care. ${ }^{1}$ The decisions to shift, transform, delay or discontinue rehabilitation care are complex. These decisions have societal implications for today and the future. This commentary describes adjustments to the continuum of rehabilitation services across 12 low-income, middleincome and high-income countries in the context of national COVID-19 preparedness responses (table 1) and provides recommendations for decision makers on the provision and payment of these essential services.

\section{CHANGES TO REHABILITATION CARE ACROSS SETTINGS}

Rehabilitation addresses health and functioning for individuals across the lifespan. The immediacy of care needs varies by condition. ${ }^{2}$ Services are provided in every setting-acute hospitals, rehabilitation hospitals, outpatient clinics, in the community and in people's homes-and resources vary by region. Guidance for the delivery of rehabilitation during COVID-19 is available for physiotherapy but not yet all rehabilitation professions. ${ }^{3}$ Several regions reported fewer non-urgent rehabilitation patient admissions in order to expand

\section{Summary box}

Rehabilitation services are essential: They need to continue during a pandemic and after as they are an essential component of high-value care offered for individuals across the lifespan to optimise physical and cognitive functioning to reduce disability.

- Rehabilitation care is affected: Globally, the response to COVID-19 is shifting rehabilitation services provided in all settings, introducing new burden on patients, families and healthcare workers.

- Measurement needed: A core set of measures needs to be adopted to monitor the health and functional outcomes for COVID-19 and other patients at risk for functional decline and to assess the quality, availability and accessibility of services today and as our nations recover.

- Telerehabilitation is necessary: Remote delivery of care and the necessary rapid scale-up of telehealth could be optimised if financial, infrastructure, resource, training and cybersecurity barriers were addressed.

- Collaboration can support needs in the home: Novel partnerships that include the rehabilitation community could enhance communication and delivery of safe and effective home-based rehabilitative strategies to mitigate the consequences of COVID-19 and reduced service capacity.

- Direct care providers need personal protective equipment: Rehabilitation providers in all settings should be ensured personal protective equipment and training to use it effectively.

acute care bed capacity. Lengths of inpatient stays for patients who receive rehabilitation are now shorter in several countries including Belgium, India, Tanzania and the UK. Shorter inpatient stays reduce the time available to assess and treat patients and train family. Any need for continued home-based 
Table 1 Continuum of rehabilitation services across 12 low-income, middle-income and high-income countries in the context of national COVID-19 preparedness recommendations

\begin{tabular}{|c|c|c|c|c|}
\hline \multirow[b]{2}{*}{ Country } & \multicolumn{3}{|c|}{ National government mandated COVID-19 response } & \multirow[b]{2}{*}{$\begin{array}{l}\text { Rehabilitation services during COVID-19* } \\
\text { (inpatient, redeployment/bed shift, } \\
\text { outpatient/home and telehealth) }\end{array}$} \\
\hline & $\begin{array}{l}\text { Stay-at- } \\
\text { home order } \\
2020\end{array}$ & National response & $\begin{array}{l}\text { Guidance for 'non- } \\
\text { essential' healthcare } \\
\text { services }\end{array}$ & \\
\hline Argentina & 20 March & $\begin{array}{l}\text { National lockdown: } \\
\text { essential trips for cleaning } \\
\text { supplies, medicines and food. }\end{array}$ & Outpatient suspended. & $\begin{array}{l}\text { Inpatient rehabilitation still offered in reduced } \\
\text { capacity. } \\
\text { Other inpatient bed types converted to increase } \\
\text { acute hospital bed capacity. } \\
\text { Patients are not attending day rehabilitation } \\
\text { programmes despite programmes being open. } \\
\text { All outpatients clinics in all public and private } \\
\text { hospitals closed. } \\
\text { Physicians and therapists cannot get } \\
\text { reimbursed for video telehealth visits (neither } \\
\text { video nor telephone). }\end{array}$ \\
\hline Brazil & By state & $\begin{array}{l}\text { Containment and mitigation: } \\
\text { national guidance defined } \\
\text { essential services and } \\
\text { recommendations for social } \\
\text { distancing and foreign entry } \\
\text { restricted. }\end{array}$ & $\begin{array}{l}\text { Non-essential services } \\
\text { suspended. }\end{array}$ & $\begin{array}{l}\text { Reduced operations for inpatient rehabilitation. } \\
\text { Shift in rehabilitation personnel and outpatient } \\
\text { services, encouraged to use telemedicine. } \\
\text { Federal Council of Medicine acknowledges use } \\
\text { of telemedicine for teleorientation (distance } \\
\text { guidance, training and patient referral), } \\
\text { telemonitoring under medical supervision or } \\
\text { guidance and teleinterconsultation (between } \\
\text { physicians for diagnostic or therapeutic } \\
\text { assistance). }\end{array}$ \\
\hline Germany & 22 March & $\begin{array}{l}\text { Containment and mitigation: } \\
\text { travel restrictions, school } \\
\text { closure, closing non-essential } \\
\text { businesses and banned public } \\
\text { gatherings. }\end{array}$ & $\begin{array}{l}\text { All elective surgeries } \\
\text { and non-essential } \\
\text { services postponed. }\end{array}$ & $\begin{array}{l}\text { Acute hospitals continued early acute } \\
\text { rehabilitation. } \\
\text { Rehabilitation hospitals discontinued care for } \\
\text { chronic, non-acute problems; acute patients } \\
\text { (eg, surgery and stroke) stay as long as needed. } \\
\text { Some rehabilitation hospitals could } \\
\text { be designated as overflow hospitals. } \\
\text { Rehabilitatation personnel supporting acute } \\
\text { hospitals. } \\
\text { Outpatient rehabilitation is reduced but available } \\
\text { for high need patients/essential care. } \\
\text { Telerehabilitation for physicians and health } \\
\text { professionals in the acute COVID-19 phase } \\
\text { possible and reimbursed. }\end{array}$ \\
\hline
\end{tabular}

Continued 
Table 1 Continued

\begin{tabular}{lll}
\hline & \multicolumn{2}{c}{ National government mandated COVID-19 res } \\
\cline { 2 - 3 } Country & $\begin{array}{l}\text { Stay-at- } \\
\text { home order } \\
2020\end{array}$ & National response \\
\hline Guyana & 16 March & $\begin{array}{l}\text { Encouraging social distancing } \\
\text { and hygienic practices. } \\
\text { Established health emergency } \\
\text { operations centre. } \\
\text { Curfew and stay-at-home } \\
\end{array}$ \\
& & $\begin{array}{l}\text { policy implemented and all } \\
\text { non-essential business ordered } \\
\text { closed. }\end{array}$
\end{tabular}

Guidance for 'nonessential' healthcare services

All elective surgeries and non-essential services postponed. closed.

India 24 March $\quad \begin{aligned} & \text { National lockdown: exceptions } \\ & \text { medical and pharma services, } \\ & \text { groceries, banks, telecom, gas } \\ & \text { stations as essential services, } \\ & \text { school closures and restriction } \\ & \text { of international and most } \\ & \text { domestic travel. }\end{aligned}$

Singapore 7 April
National lockdown: temp.
screening, hospital and home
quarantines, extensive tracing,
social distancing, bans on large
gatherings, schools closed and
travel restricted.

Non-essential elective surgeries postponed

Non-essential appointments, including elective procedures and outpatient rehabilitation, deferred. A significant proportion of outpatient providers .

Limited outpatient rehabilitation personne focused on postacute and shifted to small teams for physical distancing.

All group and community-based rehabilitation activities suspended including day rehabilitation and senior activity centres.

Home rehabilitation requests subject to review by health authorities, restricted to patients with significant new-disability and limited caregiver support.

In-hospital rehabilitation consults and multidisciplinary team meetings through teleconference.

Providers trained to deliver teleconsultations with national regulatory guidance for quality and cybersecurity. 


\begin{tabular}{|c|c|c|c|c|}
\hline \multirow[b]{2}{*}{ Country } & \multicolumn{3}{|c|}{ National government mandated COVID-19 response } & \multirow[b]{2}{*}{$\begin{array}{l}\text { Rehabilitation services during COVID-19* } \\
\text { (inpatient, redeployment/bed shift, } \\
\text { outpatient/home and telehealth) }\end{array}$} \\
\hline & $\begin{array}{l}\text { Stay-at- } \\
\text { home order } \\
2020\end{array}$ & National response & $\begin{array}{l}\text { Guidance for 'non- } \\
\text { essential' healthcare } \\
\text { services }\end{array}$ & \\
\hline Spain & 14 March & $\begin{array}{l}\text { National lockdown: exceptions } \\
\text { medical and pharmacy services, } \\
\text { groceries and banks. School } \\
\text { closures and restriction of } \\
\text { international travel. }\end{array}$ & $\begin{array}{l}\text { Non-essential services } \\
\text { suspended, non-urgent } \\
\text { surgeries postponed } \\
\text { and outpatient clinics } \\
\text { closed. }\end{array}$ & $\begin{array}{l}\text { Inpatient rehabilitation offered in reduced } \\
\text { capacity. } \\
\text { Rehabilitation beds shifted to extend capacity of } \\
\text { acute care. } \\
\text { Outpatient rehabilitation programmes } \\
\text { suspended. All outpatient clinics in all public } \\
\text { and private hospitals closed. } \\
\text { The majority of home-based rehabilitation (but } \\
\text { not completely) suspended. } \\
\text { Physicians and therapists cannot get } \\
\text { reimbursed specifically for telehealth visits } \\
\text { (neither video nor telephone as of } 23 \text { April). } \\
\text { In some contexts (eg, Catalonia) the Board of } \\
\text { Physical Therapists organised a task force of } \\
\text { volunteer physical therapists who can deliver } \\
\text { some telephone-based rehabilitation. (Provision } \\
\text { of healthcare is regulated and reimbursed } \\
\text { regionally.) }\end{array}$ \\
\hline Tanzania & Local only & $\begin{array}{l}\text { Containment and mitigation: } \\
\text { public gatherings ban, 30- } \\
\text { day closure of schools, } \\
\text { universities, training } \\
\text { institutions, health screening } \\
\text { at points of entry, 14-day } \\
\text { quarantine for travellers from } \\
\text { high-risk countries. }\end{array}$ & $\begin{array}{l}\text { Local KCMC. } \\
\text { Example: care } \\
\text { for older adults } \\
\text { suspended unless } \\
\text { an emergency, } \\
\text { outpatient block } \\
\text { appointments, } \\
\text { reduced elective } \\
\text { surgeries and } \\
\text { prioritised } \\
\text { emergency } \\
\text { surgeries. }\end{array}$ & $\begin{array}{l}\text { Inpatient rehabilitation offered but length } \\
\text { of stay and visitors reduced to prevent } \\
\text { hospital acquired infection (affecting amount } \\
\text { of time therapists have to evaluate and } \\
\text { treat patients+train family for home-based } \\
\text { rehabilitation). } \\
\text { Shift in rehabilitation personnel with those age } \\
\text { >55 years exempt from patient contact. } \\
\text { Outpatient rehabilitation appointments } \\
\text { scheduled in blocks to avoid overcrowding and } \\
\text { congestion especially in waiting areas. } \\
\text { Telehealth not a standard of practice for } \\
\text { rehabilitation (and not covered by insurance); } \\
\text { patients discharged early and appointments } \\
\text { delayed/cancelled have limited access to care. }\end{array}$ \\
\hline USA & $\begin{array}{l}\text { By state or } \\
\text { city }\end{array}$ & $\begin{array}{l}\text { Stay at home orders, school } \\
\text { closures, bans of mass } \\
\text { gatherings and non-essential } \\
\text { business closures. }\end{array}$ & $\begin{array}{l}\text { Recommendations to } \\
\text { postpone all elective } \\
\text { surgeries and non- } \\
\text { urgent procedures and } \\
\text { visits. }\end{array}$ & $\begin{array}{l}\text { Fewer rehabilitation beds; beds converted for } \\
\text { acute care. } \\
\text { Shift in rehabilitation personnel to acute } \\
\text { inpatient and telemedicine follow-up. } \\
\text { Outpatient rehabilitation available only for high } \\
\text { need patients following. CDC recommendations } \\
\text { for essential care. } \\
\text { Rehabilitation teleconsultations. Slow scale to } \\
\text { virtual visits. Physicians reimbursed. Therapists } \\
\text { reimbursed by some private insurers but not } \\
\text { reimbursed by government insurance until } 30 \\
\text { April. }\end{array}$ \\
\hline UK & 23 March & $\begin{array}{l}\text { National lockdown: only } \\
\text { leave home for food, health } \\
\text { reasons, work and other travel } \\
\text { restrictions. } \\
\text { Social distancing and personal } \\
\text { hygiene guidelines. }\end{array}$ & $\begin{array}{l}\text { Non-urgent surgeries } \\
\text { postponed. }\end{array}$ & $\begin{array}{l}\text { Hospital inpatients medically fit discharged } \\
\text { early; inpatient rehabilitation offered in reduced } \\
\text { capacity. } \\
\text { Shift in rehabilitation hospital beds to maximise } \\
\text { inpatient capacity; shift in rehabilitation } \\
\text { personnel to provide greater acute hospital and } \\
\text { community service support. } \\
\text { Outpatient rehabilitation at reduced capacity. } \\
\text { Telephone and digital/video-based consultation. }\end{array}$ \\
\hline
\end{tabular}


care has implications for caregivers particularly while social distancing.

In addition to shorter lengths of inpatient stays, all 12 countries report outpatient and home-based rehabilitation care suspended or operating at reduced service capacity. These inevitable decisions for protection of both healthcare workers and the general public may result in increases in disability and morbidity from a lack of necessary rehabilitation care to those with continued care needs. Patients at home with limited ability to move independently or facilitate their own self-care activities, and patients with prolonged hospitalisation for COVID-19 who have returned home, are at high risk of several adverse health effects. Skin breakdown, muscle weakness, joint stiffness, reduced range of motion, changes to bowel and bladder functioning, venous stasis, oedema, decreased rate of metabolism and respiratory movement, lowered mood and depression are measurable in the first week of limited mobility. It is critical that public health communication continue to address the significance of daily activity and movement while uniquely considering limitations of individuals with significant physical or cognitive disability. Guidance needs to also ensure the safety of caregivers involved and be provided for households without available caregivers.

\section{PROTECTING PROVIDERS OF DIRECT CARE}

While there is concern for people with unmet rehabilitation needs, it is important to protect all direct care providers, paid and unpaid, during a pandemic response. Many components of rehabilitation care require patient contact, for example, treating patients weaning from mechanical ventilation, developing patients' balance techniques after stroke and fitting a new limb after amputation. Furthermore, rehabilitation personnel from Guyana to Singapore are being redeployed to meet needs in care settings different than their usual work environment. In Spain, health workers represent $15 \%$ of all COVID cases and, in response, the country has mobilised retirees, medical residents or other health personnel. In Singapore, private sector and retired rehabilitation staff may join frontline healthcare. In planning for adequate personal protective equipment and training for its use, governments need to include all direct care providers in their calculations to adequately protect people in homes and community-based settings when direct-patient contact is still necessary.

\section{TELEREHABILITATION}

Telephone consultation for care is an option in some regions but is dependent predominantly on the availability of personnel. Use of video visits and other forms of virtual care, although preferred for rehabilitation over telephone consultation alone, requires widespread and stable internet connectivity, availability of technology for both the rehabilitation provider and the patient, 'tech literacy' or the ability to use a device, the availability of 'tech support' to troubleshoot or first get connected and payment for provider time. Although rehabilitation in some countries such as Guyana, Germany and the UK is a component of universal healthcare coverage (UHC), governments and health insurers of other non-UHC countries need to pay therapists, in addition to physicians, to equitably provide care via telehealth.

Use of telehealth under usual circumstances in all forms-text, telephone and video-requires planning, training and iterative improvement. It is imperative that experienced telehealth providers share protocols and become champions to support their peers with rapid scale-up in this challenging environment. Publications are emerging, and some professional societies are sharing guides for remote consultations ${ }^{45}$ China and the USA have live webcast sessions with national experts to train rehabilitation providers and online communities to empower caregivers. Creative solutions to use free and commercially available communication tools like WeChat and WhatsApp are being used in Brazil, China and Guyana. These approaches are limited in Tanzania and likely other low-income countries due to costs for data plans and limited in-home internet access. With the majority of rehabilitation care provided remotely during a pandemic response, telehealth strategies need the infrastructure and to be resourced and financed appropriately.

\section{MEASURING THE IMPACT OF COVID-19}

Enhanced measurement and monitoring are desperately needed at the individual, health system and national levels. With the release of the WHO Rehabilitation Guide for Action only this past year, ${ }^{6}$ few countries had fully completed a systematic assessment of the rehabilitation situation and developed a strategic plan to adequately meet rehabilitative needs prior to this pandemic or to activate during pandemics. Yet, today, we need alignment on a measurement strategy. Longitudinal assessments of health and functional outcomes are needed to monitor individual and population health and support clinical decision making for allocation of scarce resources in all settings.

The global significance of measurement on practice and policy was evident in the release of COVID-19 outcomes assessments of intensive care unit patients ${ }^{7}$; similar data are needed on the functional recovery of patients with COVID-19. Service-level records need to be monitored to ensure adequate quality and equity with constrained resources. In the longer term, greater attention to national census and cohort surveys will be needed to detect changes in population health that can inform policy decisions on rehabilitation service needs and geographic disparities. The rehabilitation community needs to unite to consider a core set of measures to monitor recovery of patients with COVID-19, health of persons with disability and chronic conditions, and the 
quality, availability and accessibility of services today and as our nations recover.

\section{RECOMMENDATIONS}

Rehabilitation care is at a unique turning point. In 2017, the WHO had already noted 'substantial and everincreasing unmet need for rehabilitation services worldwide'. ${ }^{8}$ Today, we are faced with a new population of patients at risk of functional decline in addition to the disability pandemic already present among one billion people globally. We are providing care in new ways and standards of care are changing. The following recommendations are provided to mitigate the consequences of COVID-19's impact on rehabilitation care and support continued health with reduced risk of disability.

- Governments need to include rehabilitation and other direct care providers in home-based and community-based settings in their plans for personal protective equipment acquisition and training.

- Global collaboration across rehabilitation professionals needs to accelerate the sharing of resources, instructional tools, education and training packets for how patients and families can continue rehabilitation at home during a pandemic response.

- Public health messaging on mental and physical health while social distancing needs to expand with input from rehabilitation professionals to provide guidance for persons living with physical and cognitive limitations, with and without caregivers.

- Public-private partnerships are needed to better support rapid scale of telehealth today and in the future to ensure effective use, financing, cybersecurity, access and increased reliability of broadband networks to reach people in low-resourced areas.

- The rehabilitation community needs to unite on measurement of care and outcomes because the evidence established in real world practice today could transform care and lives tomorrow.

\section{CONCLUSIONS}

The WHO called on nations to ensure continuity of essential services in parallel to scaling public health preparedness and response measures. ${ }^{9}$ Our shared experience is that national agencies did not issue specific guidance for the provision of rehabilitation. Considerations for service delivery balanced risk of transmission with both the availability of resources to provide care and the patient's acuity, level of urgency and potential for harm if services were postponed or altered. Rehabilitation service providers mobilised quickly to provide the best, safest care possible to those in greatest need; decisions were in many cases made locally. Looking beyond the pandemic, rehabilitation needs to remain at the forefront of discussions for UHC; barriers to infrastructure, implementation and financing care via telehealth and alternative approaches need to be eliminated. Strong leadership for inclusion of rehabilitation in public health and healthcare policymaking is acutely needed to ensure high-value care and reduce the global burden of disease.

\section{Author affiliations}

${ }^{1}$ Department of Orthopaedic Surgery, Duke University, Durham, North Carolina, USA

${ }^{2}$ Duke-Margolis Center For Health Policy, Duke University, Washington, District of Columbia, USA

${ }^{3}$ Intensive Care Unit, Austral University Hospital, Pllar, Buenos Aires, Argentina

${ }^{4}$ Rehabilitation Department, AZ Rivierenland, Bornem, Belgium

${ }^{5}$ Faculdade de Medicina, Universidade de Sao Paulo, Sao Paulo, Brazil

${ }^{6} \mathrm{Hospital}$ das Clinicas, Universidade de Sao Paulo, Sao Paulo, Brazil

${ }^{7}$ Pinetree Care Group, Beijing, P. R. China

${ }^{8}$ Medical Park Berlin Humboldtmühle, Berlin, Germany

${ }^{9}$ Disability and Rehabilitation, Ministry of Public Health Guyana, Georgetown, Guyana

${ }^{10}$ Physiotherapy, Christian Medical College and Hospital Ludhiana, Ludhiana,

Punjab, India

${ }^{11}$ Rehabilitation Medicine, Singapore General Hospital, Singapore

${ }^{12}$ Bright Vision Hospital, SingHealth Community Hospitals, Singapore

${ }^{13}$ Physiotherapy, Singapore General Hospital, Singapore

${ }^{14}$ Intermediate Care, Research and Teaching, Parc Sanitari Pere Virgili, Barcelona, Spain

${ }^{15}$ Kilimanjaro Clinical Research Institute, Kilimanjaro Christian Medical Center,

Moshi, United Republic of Tanzania

${ }^{16}$ Physiotherapy, Kilimanjaro Christian Medical Center, Moshi, United Republic of Tanzania

${ }^{17}$ Therapies Department, Chelsea and Westminster Hospital NHS Foundation Trust, London, UK

${ }^{18}$ Physical Therapy and Occupational Therapy, Department, Duke University Health System, Durham, North Carolina, USA

${ }^{19}$ Burke Rehabilitation Hospital, Montefiore Health System, New York, New York, USA

${ }^{20}$ Rehabilitation and Regenerative Medicine Department, Columbia University Vagelos College of Physicians and Surgeons, New York, New York, USA

Twitter Janet Prvu Bettger @jpbettger, Victoria Marquevich @vickymar28 and Ninie Wang @WangNinie

Contributors All authors led to the study's conceptualisation and design, scientific leadership, narrative development, local data and provided final approval.

Funding The authors have not declared a specific grant for this research from any funding agency in the public, commercial or not-for-profit sectors.

Competing interests None declared.

Patient consent for publication Not required.

Provenance and peer review Not commissioned; externally peer reviewed.

Data availability statement There are no data in this work.

Open access This is an open access article distributed in accordance with the Creative Commons Attribution Non Commercial (CC BY-NC 4.0) license, which permits others to distribute, remix, adapt, build upon this work non-commercially, and license their derivative works on different terms, provided the original work is properly cited, appropriate credit is given, any changes made indicated, and the use is non-commercial. See: http://creativecommons.org/licenses/by-nc/4.0/.

\section{ORCID iD}

Janet Prvu Bettger http://orcid.org/0000-0001-9708-8413

\section{REFERENCES}

1 Institute of Medicine. Best care at lower cost: the path to continuously learning health care in America. Chapter 8. achieving and rewarding high-value care. Washington, DC: The National Academies Press, 2019. https://doi.org/

2 Cieza A. Rehabilitation the health strategy of the 21 st century, really? Arch Phys Med Rehabil 2019;100:2212-4.

3 Thomas P, Baldwin C, Bissett B, et al. Physiotherapy management for COVID-19 in the acute hospital setting: clinical practice recommendations. J Physiother 2020. doi:10.1016/j. jphys.2020.03.011. [Epub ahead of print: 30 Mar 2020]. 
4 United Kingdom Chartered Society of Physiotherapy. COVID-19: guide for rapid implementation of remote consultations. Available: https://www.csp.org.uk/publications/covid-19-guide-rapidimplementation-remote-consultations [Accessed 10 Apr 2020].

5 World Confederation for Physical Therapy and international Network of Physiotherapy Regulatory Authorities. Report of the WCPT/INPTRA digital physical therapy practice, 2019. Available: https://www.wcpt org/sites/wcpt.org/files/files/wcptnews/REPORT\%20OF\%20THE\% 20WCPTINPTRA\%20DIGITAL\%20PHYSICAL\%20THERAPY\% 20PRACTICE\%20TASK\%20FORCE.pdf [Accessed 10 April 2020].

6 World Health Organization. Rehabilitation in health systems: guide for action. Geneva: World Health Organization, 2019.
7 Grasselli G, Zangrillo A, Zanella A, et al. Baseline characteristics and outcomes of 1591 patients infected with SARS-CoV-2 admitted to ICUs of the Lombardy region, Italy. JAMA 2020;323:1574-81.

8 World Health Organization. Rehabilitation, 2030. Available: https:// www.who.int/disabilities/care/rehab-2030/en/ [Accessed 10 April 2020].

9 World Health Organization. COVID-19 strategic preparedness and response plan, 2020. Available: https://www.who.int/docs/defaultsource/coronaviruse/covid-19-sprp-unct-guidelines.pdf?sfvrsn= 81ff43d8 4 [Accessed 10 Apr 2020]. 